\title{
ENVIRONMENTAL AND TERRITORIAL PLANNING ON COASTAL METROPOLITAN AREAS. A METHODOLOGICAL PROPOSAL FOR VALENCIA (SPAIN)
}

\author{
JOSÉ LUIS MIRALLES I GARCIA ${ }^{1}$ \\ Department of Urban Planning, Polytechnic University of Valencia, Spain
}

\begin{abstract}
Currently, the mature metropolitan areas have special characteristics. On the one hand, its population is stabilized or has small growths. However, on the other hand, the artificial land increases. These areas present new dynamics in the last period: urban sprawl, transformation of rural or natural areas to artificial lands, increase of mobility, land demands for new uses, abandonment and degradation of consolidated urban land. This new reality needs a new vision to plan and manage these areas. Particularly, the new problems are more strong in coastal metropolitan areas because of in these areas the conflicts between territorial uses are very intensed. València is a Spanish city in the Mediterranean coast. The Mediterranean coast of València, where is its metropolitan area, had a period of economic expansion from 1997 to 2007 and is currently in the economic crisis period initiated in 2008. The metropolitan area of València includes a large list of very different uses with its own dynamics, often contradictory among them. For exemple, there is an important touristic activity in beaches next to protected areas as the historical agricultural land named "Horta" or the Natural Park of L'Albufera. The urban expansion for differents urban uses (big transport infrastructures, touristic activities, entertainement activities, sea port expansion, ...) is contradictory to the conservation of these natural resources in open spaces. Recently, the European Union developed the concept of green infrastructure in order to guarantee the Natural Capital including urban areas. This article has an objective to analyse the current dynamics in the metropolitan area of Valencia and design a planning process where environmental issues are essential and determinant, keeping in mind governance issues.

Keywords: green infrastructure, landscape and urban planning, regional planning, strategic environmental assessment.
\end{abstract}

\section{INTRODUCTION}

There is a worldwide trend of population concentration in urban areas. More than half of the world's population lives in urban areas with a tendency to increase. These processes of urban concentration present specific dynamics in the mature metropolitan areas of the more developed countries, especially in the 21st century during the urban expansion period 1997-2007 and the period of real estate crisis from 2008 to the present. According to Wheeler [1], which studied the dynamics of six metropolitan regions of US in period 1980-2005, the dynamics was characterized by:

- A very big increase of their urbanized land areas and a very big increase of surface of metropolitan areas.

- An important decrease of the density of both population and houses in metropolitan regions.

In addition, this author identified nine patterns or built landscape forms in metropolitan regions of United States: rural sprawl, tract development, upscale fringe, multifamily housing, trailer parks, new urbanist landscapes, incremental subdivision, commercial and industrial.

'ORCID: http://orcid.org/0000-0001-5638-2608 
Table 1: Population evolution of metropolitan areas of Spain. Source: Feria et al. [5].

\begin{tabular}{lccllll}
\hline \multirow{2}{*}{ Metropolitan area } & 2001 & & 2011 \\
\cline { 2 - 3 } Madrid & Municipalities & Population & & Municipalities & Population \\
Barcelona & 172 & $5,623,784$ & & 172 & $6,729,769$ \\
Valencia & 130 & $4,340,618$ & & 139 & $5,088,201$ \\
Sevilla & 74 & $1,594,762$ & & 80 & $1,935,363$ \\
Málaga-Marbella & 49 & $1,369,708$ & & 51 & $1,581,798$ \\
\hline
\end{tabular}

In Spain, there was an expansive economic cycle based on real estate speculation in the period 1997-2007 and the ensuing economic crisis that began in 2008 and which still stands today [2], with special consequences in touristic coastal zones [3].

Aguilera et al. [4] analysed the dynamics of metropolitan area of Granada (Spain) and the urban growth patterns. They identified similar dynamics and a list of three patterns: residential intense development, industrial and commercial specialization and compact development. The processes resulted in the fragmentation and occupation of the rural landscape and the expansion of the urban structure of metropolitan areas.

Feria et al. [5] studied the dynamics of metropolitan areas of Spain between 2001 and 2011. He observed that, in the case of Spain, metropolitan areas increase populations during the period of real state bubble as you can see in Table 1 but, in the crisis period, its population remained stable or decreased. He thinks that this trend will continue. In spite of that, it continues the process of metropolitan areas expansion, urban sprawl and decreasing densities. That is the case of metropolitan area of Valencia, a metropolitan area in Spain, next to Mediterranean Sea.

So, it is necessary know the new reality of metropolitan areas to generate policies in order to improve the sustainability of metropolitan territory by planning [6]. In this situation, environmental issues are essentials.

On the other hand, the European concept of regional/spatial planning was defined on the European Charter on Regional Planning aproved by the 6th European Conference of Ministers responsibles for Regional Planning (CEMAT) celebrated in Torremolinos (Spain) in 1983. [7]. According to this concept, the fundamental objectives of regional/spatial planning are:

- Balanced socio-economic development of the regions

- Improvement of the quality of life

- Responsible management of natural resources and protection of the environment]

- Rational use of land

In addition, the Charter defines specific objectives. Between them, there is an objective about coastal areas and islands:

The development of mass tourism and transport in Europe, and the industrialisation of coastal areas, islands and the sea, demand specific policies for these regions in order to ensure their balanced development and co-ordinated urbanisation, bearing in mind the 
requirements of environmental conservation and regional characteristics. Regard must be given to the specific role and functions of coastal areas in the land-sea relationship and of sea-transport possibilities.

However, in fact, particularly in Spain, in general, the main objectives of regional planning were focused for a long period in socio-economic development. In Spain, there were three periods of real state bubbles with important urban expansions (1959-1972; 1985-1991; 1997-2007) [8]. Therefore, metropolitan areas have a general dynamic of spatial expansion without population growth. In this scenario, it is very important to protect and maintain natural resources, but it is more important to promote and design ecosystems that include urban spaces or artificial spaces.

In Spain, all urban developments are carried out in execution of the current urban planning. Therefore, the urban plan is a determinant instrument to anticipate urban and nonurban uses and its design. Current Regional Government is revising regional planning for different areas of the territory of Valencian Country. In addition, in Europe, the Directive [9] about strategic environmental assessment (SEA) is valid and translated to Spain in 2006. These Directive and Spanish law establishes significant conditions in proceedings to elaborate plans and urban programmes. More recently, the concept of green infrastructures arises in European environmental policy [10]. Therefore, it is the right time to review methodologies to regional planning, especially in coastal areas where most of human activity is concentrated. The metropolitan area of Valencia is a good territorial reference to think these new methodologies.

\section{MAIN DYNAMICS IN VALENCIA METROPOLITAN AREA}

The metropolitan area of Valencia may have different borders dependent on the criteria used to identify it. Accordint to criteria defined on Valencian Community's Territorial Strategy [11], the functional area of Valencia covers an area of $3,897 \mathrm{~km}^{2}$ with a population of $1,774,550$ inhabitants in 2015. The area includes 90 municipalities. In Fig. 1, it is possible to observe the surface occupied by the metropolitan area according to a study realized by the author's research team UDR F.Eiximenis in 2003. The surface of metropolitan area in 2003 was very similar to the current one.

In 2005, the population of this area was $1,740,335$ inhabitants that increases to $1,807,826$ in 2015 according to the dates of Initial Document or Draft Plan of Metropolitan Plan of Valencia [12]. Regarding land uses, in 2015, the area has 895 ha of urbanized land with a capacity for 22,375 new homes and 1,280 ha of commercial and industrial urbanized lands with a capacity for 51,200 new employments. These uses are a part of artificial land.

Therefore, the metropolitan area is having a moderate population's increase. However, see Table 2, the artifical surface is having a large increase according to Boira [13]. This study uses a different delimitation for the urban region of Valencia but evidences the surface's increase.

In addition, there are an important quantity of land for future urban development, see Table 3. With an average density of 25 homes/ha, residential lands planned to urban development in urban plans (named urbanizable lands in Valencian laws) have a capacity for about 150,000 homes or 375,000 inhabitants. On the other hand, lands for economic activities, with a ratio of 40 employment/ha, have a capacity for about 138,000 employments.

All this means that although the population does not grow or grow little, urban use over the territory is increasingly intense. The urban expansion in metropolitan area of Valencia has taken place in the form of urban sprawl as can be seen in Fig. 1. This implies an increase in the cost of municipal public services [14]. 


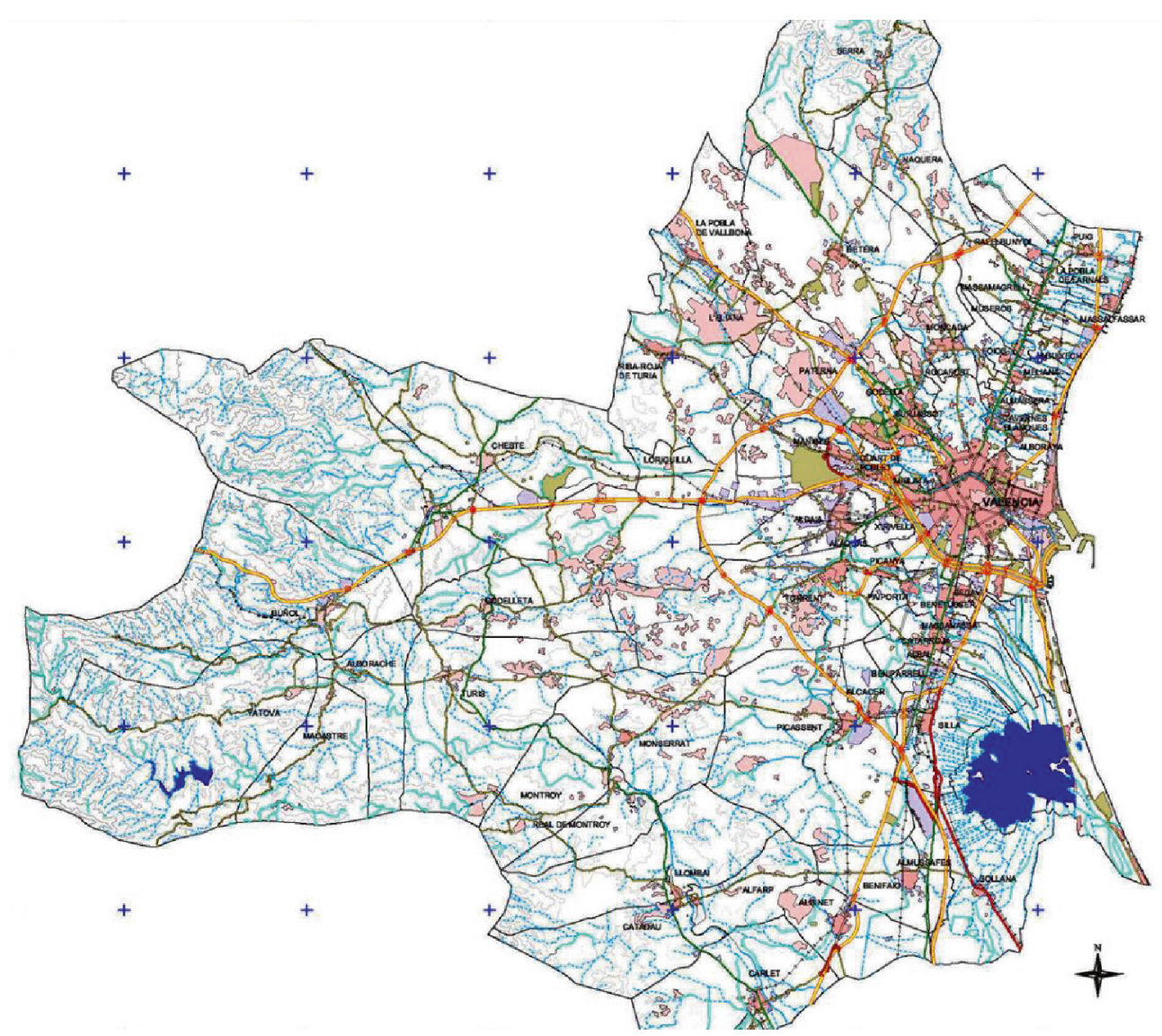

Figure 1: Metropolitan area of Valencia with urban areas in red and brown. Source: UDR F.Eiximenis.

Table 2: Population evolution and artificial land of Valencia Urban Region (1990-2006). Source: Boira [13].

\begin{tabular}{lccc}
\hline Artificial land (ha) & 1990 & 2000 & 2006 \\
\hline Valencian Community & $73,335.28$ & $109,612.90$ & $125,794.52$ \\
Valencia Urban Region & $28,116.76$ & $36,363.74$ & $41,766.75$ \\
\hline
\end{tabular}

On the other hand, this high process of urban expansion and urban sprawl produces important environmental impacts.

\section{ENVIRONMENTAL ISSUES}

Depending on the causes that produce environmental impacts, there are two possible origins:

- Environmental impacts produced by process of transformation of rural land to urban land.

- Environmental impacts produced by activities. 
Table 3: Land for urban development. Source: GVA [12].

\begin{tabular}{lc}
\hline Urbanizable land & Surface (ha) \\
\hline Residential & $6,138.86$ \\
Public facilities & $1,987.26$ \\
Economic activities & $4,464.07$ \\
- Industrial & $3,468.74$ \\
- Tertiary & 995.33 \\
TOTAL & $12,590.19$ \\
\hline
\end{tabular}

The dynamics of both processes, land transformation and activities, are very different. In general, in Spain, land transformation is possible by a territorial planning system. The correction of environmental impacts produced by land transformation only is possible by territorial planning. In fact, the land transformation from rural land to urban land is a practically irreversible process. Therefore, the correction of this kind of impacts only is possible through preventive measures by planning process. For example, the destruction of high quality agricultural lands by urban developed will only be avoid by regional planning. Figure 2 shows the big surface of high-quality agricultural lands around Valencia. In addition, other measures will be necessary to block the protection of these natural resources in the long term.

By contrast, the activities produce environmental impacts that can be corrected "a posteriori". Obviously, it is possible and desirable to prevent, totally or partially, the environmental impacts produced by urban activities and, consequently, the development of said activities must be conditioned to impact corrections. For example, the atmospheric pollution produced by urban traffic can be corrects, partially, planning mix uses in territory or, in addition, through policies to change the traffic modal split in favour of less polluting modes or changing vehicle technologies.

UDR Eiximenis team designed a methodology to identify the zones more or less appropriate to urban development conditional to capability (characteristics of territory to support urban uses in function of physical and risk conditions) and vulnerability (environmental impacts that will produce urban development if it is done) [15]. The aptitude of each homogeneous zone to urban development results as a superposition of both capability and vulnerability maps. This aptitude is also a function of kind of urban development: general urban uses, hazardous industrial uses and strategic uses. The method does not realize any weighted mean between the different geographical variables and maintains the cause-effect relationships between the values of the variables and the aptitude of the different zones of the territory to the three basic urban uses considered.

In Fig. 3, the vulnerability map of metropolitan area of Valencia to strategic uses can be seen. In this methodology, the natural resources are identified as closed polygons with homogeneous characteristics but not as a network.

In general, Mediterranean coastal landscape is a mosaic of rural and urban uses. Valencia is a Mediterranean coastal city. Around it, there are extensive zones with environmental values. The main zones in metropolitan area of Valencia with significant environmental values are the following:

- Agricultural land with high quality, especially the historical Huerta of Valencia [16, 17].

- The Natural Park of L'Albufera

- Beaches in the north and south of Valencia and Mediterranean Sea 


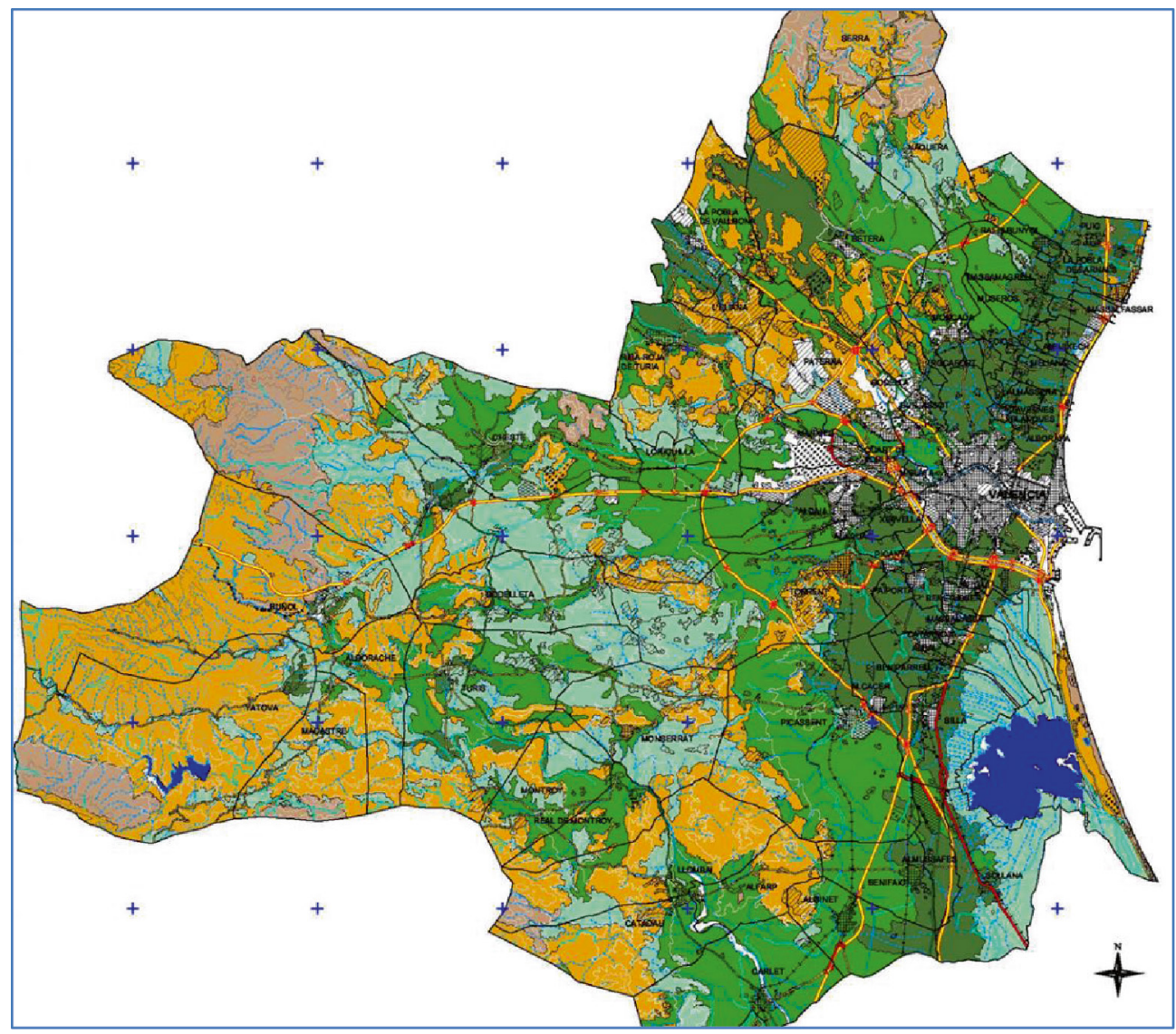

Figure 2: Agricultural lands around València in function of its agricultural capacity: very high (dark green), high (green), moderate (light blue), low (ochre), very low (brown). Source: UDR F.Eiximenis.

- Natural Park of Calderona Mountains

- Special Conservation Zones

- Túria river and riverbank and other minor rivers.

The main environmental problems are [8]:

- Reduction of irrigation lands

- Abandonment of agricultural dry land (olive tree, grapes, almond tree ...)

- Loss of diversity of the agroforestry pattern

- Territory fragmentation because of urban sprawl

- Barrier effect and ecosystem fragmentation produced by mobility infrastructures

In fact, more and more urbanized or artificial areas spread throughout the territory, involving and fragmenting natural or agricultural areas. Because of this, it is necessary to revise the process of regional planning in order to maintain landscapes, natural resources and ecosystems. 


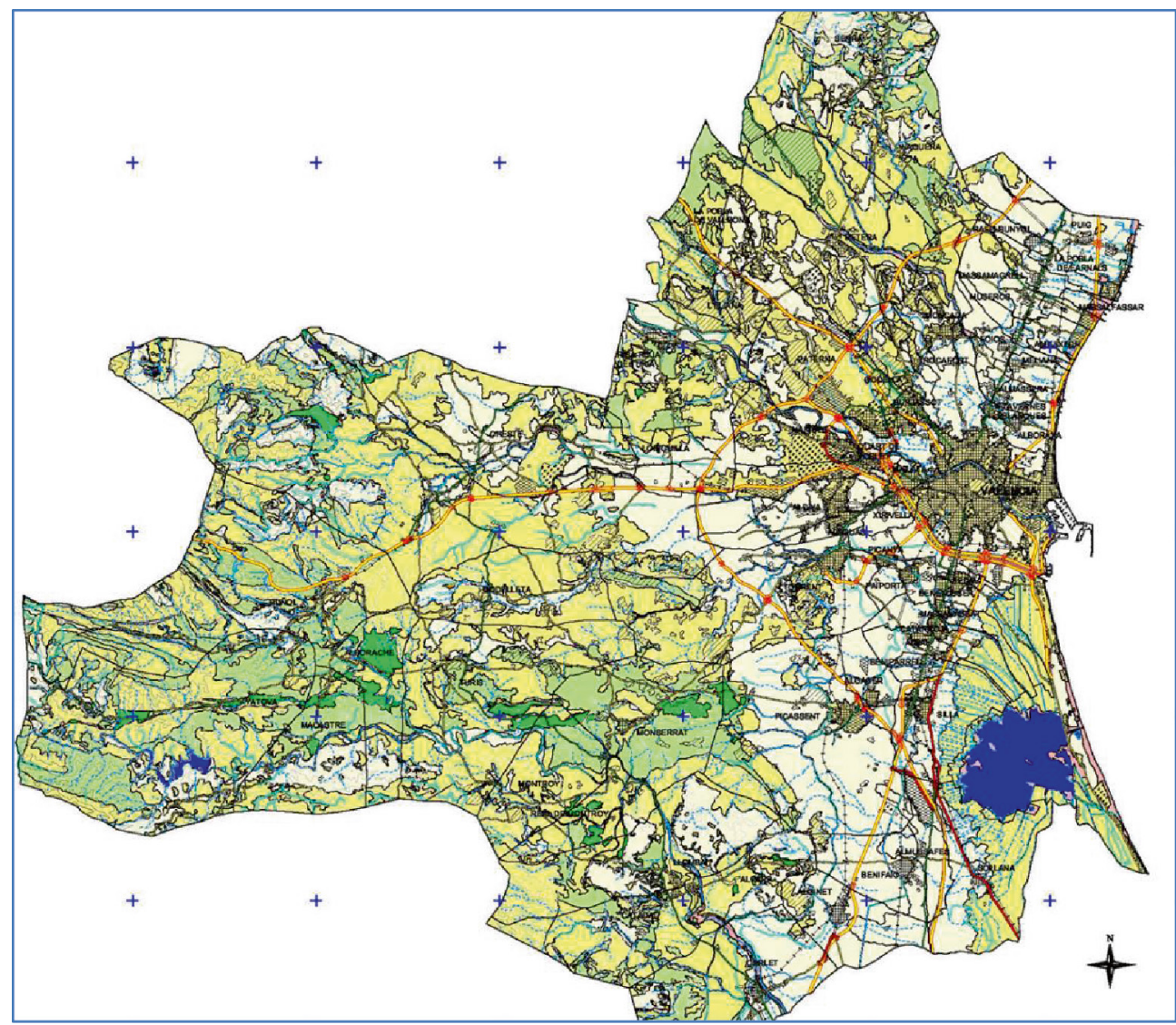

Figure 3: Vulnerability map of metropolitan area of Valencia for strategic uses: low vulnerability (green colours), average vulnerability (yellow colours), high vulnerability (red colours). Source: UDR F.Eiximenis.

\section{OBJECTIVES}

The objective of our research is make a proposal of methodology for regional/spatial planning of Mediterranean coastal urban areas based in the integration system of historical regional planning process with SEA. This new approach, based on new criteria, must allow a more efficient territorial management to maintain and improve natural resources in coastal metropolitan areas such as Valencia.

\section{ANALYSIS OF NEW CRITERIA TO INTRODUCE SPACIAL PLANNING OF COASTAL URBAN AREAS}

In Valencia, there is a large experience in regional/spatial planning [18] and urban planning. To the present, in Spain, regional and urban planning has been aimed with the main objective to order the news urban development. In addition, the municipalities obtained incomes produced by activities associated to urban development. Now, after the last real state bubble period, urban development does not exist or is very low. And besides, it is better to avoid new speculative urban developments. Therefore, the planning process must have other objectives. 
According to the analysis of the current situation of metropolitan area, the new criteria must be focused on three items:

- Green infrastructure

- System settlement

- Mobility

In addition, the regional/spatial planning process must be carried out through a SEA. In European Union, the SEA is a public participation process in decision-making for programmes and plans with environmental consequences [19].

\subsection{Green infrastructure}

The communication from Commission to the European Parliament, COM (2013) 249 final, Green Infrastructure (GI) - Enhancing Europe's Natural Capital [10], is defined green infrastructure as a strategically planned network of natural and semi-natural areas with other environmental features designed and managed to deliver a wide range of ecosystem services. It incorporates green spaces (or blue if aquatic ecosystems are concerned) and other physical features in terrestrial (including coastal) and marine areas. On land, GI is present in rural and urban settings.

Regional government of Valencia applied this concept in the last law about urban and regional planning, specifically in Regional and Urban Planning and Landscape Act of 2014 [20] but without defining any methodology to fully identify the green infrastructure, only some criteria. A list of territorial elements that must be integrated into a new network must be identified. Also, the design of green infrastructure must be carried out previously to other elements. The metropolitan area of Valencia has been taken as a geographic reference area to design the methodological proposal.

The implementation of green infrastructure is essential in currently situation of metropolitan area of Valencia. Now, the real situation of territory is a mix of rural and urban areas. Historically, regional and urban planning in Spain had as a general objective order the urban development in territory. Now the objective is, especially, to reorder the territory. In general, new urban developments are not necessary. Historical urban development produced a loss of natural resources and landscape degradation. Now it is necessary to regenerate rural, natural lands and ecosystems that today exist yet and connect them to each other to make up a network (infrastructure).

On the other hand, Valencian law stablishes a list of green infrastructure elements:

- Natura 2000 Network (at the moment this network occupies 36\% of territory)

- Protected areas by Valencian Acts

- Protected areas by international and Spain state rules

- Humid areas and aquatic ecosystems

- Marine waters associated to coastal ecosystems identified in Valencian Territorial Strategy

- Coastal areas with environmental and cultural interest identified in Valencian Territorial Strategy

- Public forests or private forests with public interest

- Agricultural areas with high quality because of different causes (productivity, safety from risks, landscape and original products)

- High-quality landscapes identified in Valencian Territorial Strategy

- Spaces with high cultural value 
- Critical areas because of natural and artificial risks identified in Valencian Territorial Strategy

- Other areas identified in urban and regional planning to integrate in green infrastructure network

These elements must be connected between them by ecological and functional corridors to allow itineraries for fauna and people by rural zones.

This approach also allows redesign general landscape and the border rural-urban landscape in metropolitan area by green belt around urban zones.

The green infrastructure improves environmental services such as climate change adaptation, natural resources, ecosystems, natural risk safety and environmental quality.

\subsection{System settlement}

In this item, according to Territorial Strategy of Valencian Community [21], the main objective is to promote a polycentric model of cities system. That is, promote different centres of residential and economic activities distributed in territory and based on currently cities system.

For that, it is necessary focus on the initiatives in urban renovation principally and by new urban development when this is not possible.

On the other hand, the Territorial Strategy of Valencian Community, approved in 2011, establishes a set of criteria for the planning of municipal urban development through urban planning. In general, most of the current municipal urban plans were approved prior to this strategy. But, it is possible to revise the municipal urban plans for metropolitan area. Particularly, the currently land planned to future urban development (urbanizable land) must be revised and change planned situation to rural land (not urbanizable land) if location or extension not meet currently sustainability conditions approved in Territorial Strategy of Valencian Community.

The nodes of polycentric cities system must be compact cities with a mix of urban uses and adequate size to allow viable public transport. These polycentric cities system must be designed after the design of rural green infrastructure, which complements.

After design of the settlement system, it is possible complete the design of green infrastructure with the definition and design of this network in the urban areas (urban green infrastructure) connected to the general green infrastructure. This urban network is thinking as a corridor for pedestrian people or cyclists. Therefore, at urban scale, this network must also be connected with the main transport centres or intermodal nodes. In consequence, this criterion implies redesign significant public spaces, for example intermodal stations, as friendly spaces integrated in green infrastructure.

\subsection{Mobility}

Currently, the general objective for mobility is the sustainable mobility according to the general policy of Europe, Spain and municipalities. This objective must be addressed at different scales: at the European, regional and local scales.

For example, Valencia is a node of Mediterranean Corridor (see Fig. 4), and it is necessary to draw the transport infrastructures for this project. Mediterranean Corridor is an Europena Axis to structure merchandise transport along north-south Europe. Note you that historical spanish railroad network have different width that Europena network. Thus it is necessary adapt historical rail lines or build new ones. This axis can serve to distribute merchandises throughout Europe and is considered as a strategic transport axis for Europe. 


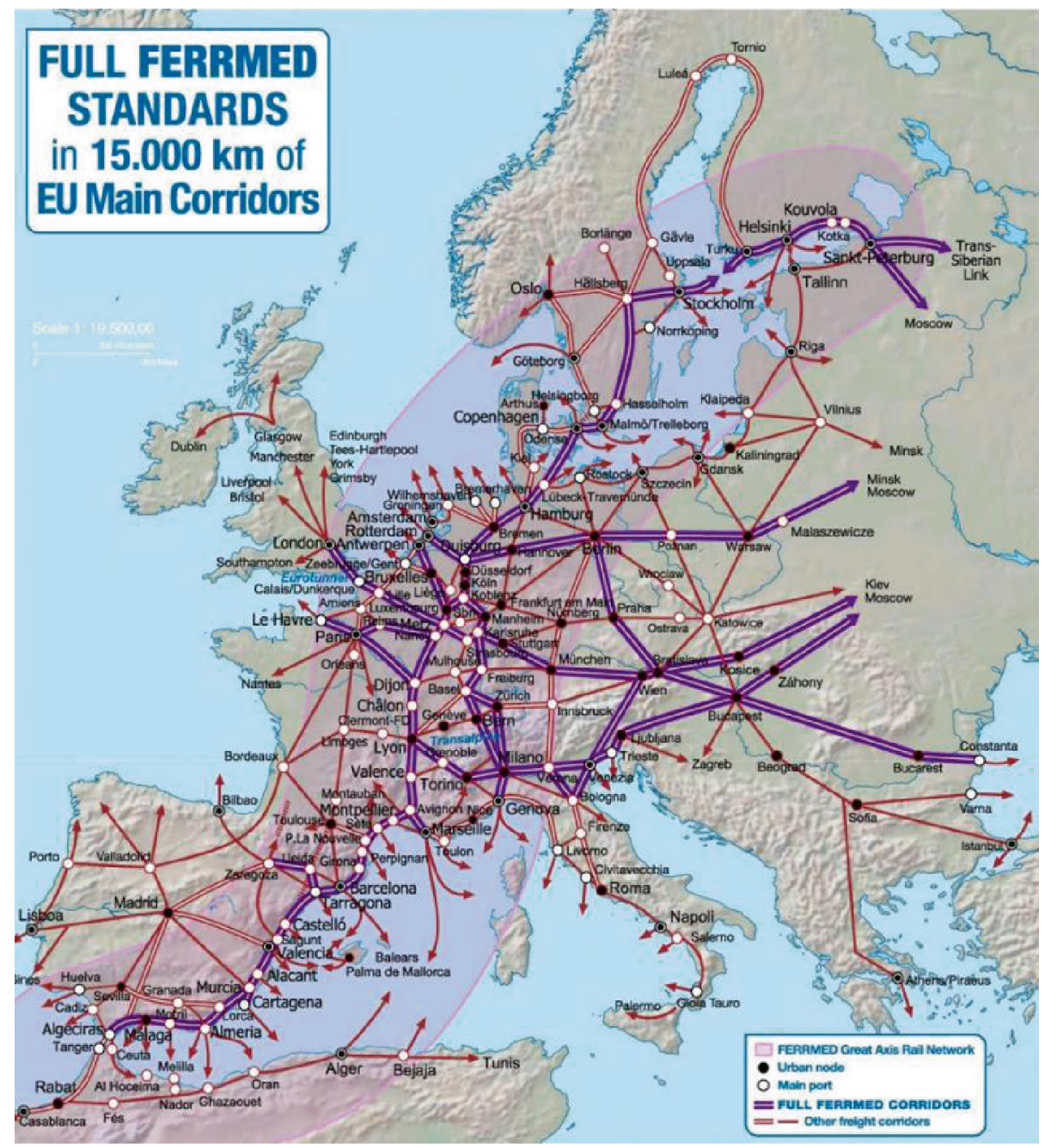

Figure 4: Mediterranean Corridor. Source: FERRMED [24].

From the point of view of metropolitan internal mobility, the objective of sustainable mobility implies to promote public transport and not motorized transport. However, this can only be achieved through intermodality, that is, through combined trips with various modes of transport as a public transport by bus or by train, bicycle, walking, car ...

The final objective is decreasing trips by car and increasing trips by public transport or not motorized transport.

This objective require plan uses in metropolitan territory to improve efficiency of public transport. In fact, a model of transport-oriented development [22, 23] establish city models based in axis transit. Particularly, this objective can be achieved by concentrating population and economic activities around transport nodes with intermodal stations. These stations must be designed with parking spaces for cars and bicycles so that people can go walking, by bicycle or by car to intermodal stations to take a bus or train. 
An efficient public transport requires a high frequency of travel services. These services only are possible if population and activities are concentrates near to stations. Therefore, the settlement system must be designed as compact nodes around stations. The urban uses scattered throughout the territory should be avoided.

In this case, the transport infrastructures must adapt to these objectives. It will probably be advisable to modify the existing infrastructure paths to achieve those objectives.

On the other hand, it will be necessary to draw the routes for different long-distant transport corridors. Particularly, it will be necessary to draw the route of new infrastructures to Mediterranean Corridor and its logistics spaces associated. Even though the corridor is planned to merchandise train transports, it will be necessary to also design the route for high-speed train to connect Valencia and Barcelona (today Valencia is connected by high-speed train with Madrid and the public works for infrastructure connecting with Murcia in the south are very advanced).

All these infrastructures produce barrier effect and ecosystem fragmentation in the territory $[24,25]$. To avoid this effect, it will be necessary to integrate the transport infrastructures in territory in general and particularly in green infrastructure in order to facilitate walkways or crossing between the two sides and design a good final landscape.

\subsection{Strategic environmental assessment}

The European Directive 2001/42/CE of 27th June 2001, on the assessment of environmental effects of certain plans and programmes is developed in Spain by Law 21/2013 of 9th December 2013, on environmental assessment. Regional laws complement this state Law. In Valencia, the currently regional law is the Law 5/2014 of 25th July 2014, on regional planning, urbanism and landscape of Valencian Community.

The process of SEA of regional and urban planning according to Valencian laws has the following phases:

- Declaration of the start process for the elaboration of a plan or programme.

- Elaboration of Initial Document of plan or programme or Draft plan/programme.

- Elaboration of plan/programme.

- Elaboration of Environmental Report of plan/programme.

- Public participation to decision-making.

- Analyse public participation process, modify the plan or programme if necessary according to suggestions and respond to stakeholders.

- Elaboration of final document of plan/programme.

- Elaboration of Environmental Declaration.

- Communication and public exposition of the final documents.

According to these phases, after Initial Document to define the boundaries of investigation, assessment and assumptions required in the environmental assessment, a first version of plan or programme must be carried out. This first version will be public to informing and consulting the public to decision taking.

The methodologic proposal developed focuses on the preparation of this first version of plan and its revision after the phase of decision taking. 


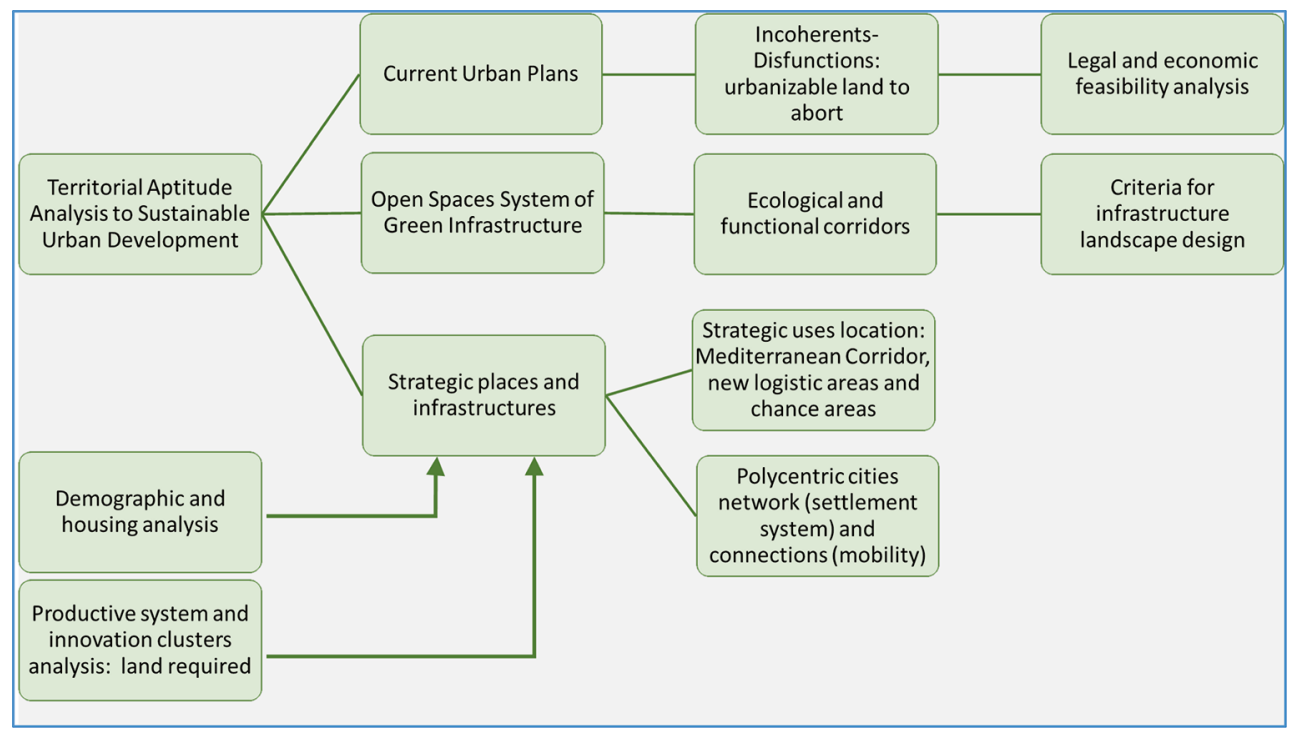

Figure 5: General methodology to process of metropolitan planning.

\section{RESULTS: METHODOLOGIC PROPOSAL TO PLANNING PROCESS}

In this current situation, it is necessary to revise the methodology of territorial planning. Figure 5 shows the general methodology designed. This is a methodology for planning metropolitan or urban areas based in territorial aptitude method to sustainable urban development (PMABASUD). The methodology is designed as a development of territorial aptitude method to sustainable urban development thinking in metropolitan area of Valencia, in the Spanish Mediterranean coast.

The process starts with the identification of Natural Capital to reserve for the future by Aptitude Method for Sustainable Urban Development.

The analysis of aptitude allows three news analysis: Open spaces system, coherence of currently local urban plans of metropolitan area and strategic location for development and infrastructures.

The aptitude method allows to determine the elements of land to reserve for the future. These elements constitute the system of open spaces of the green infrastructure of metropolitan area that produces significant environmental services. Given that it is a coastal metropolitan area, the elements of coastal landscapes are especially important to maintain the tourist attraction of the coast.

With open spaces system defined, understood as a set of homogeneous polygons of the territory or environmental units with specific functions of environmental services which justify their maintenance and improvement for the future, it is possible to define the ecological and functional corridors to connect open spaces between them. This analysis is performed on a territorial scale.

Finally, the design criterion for infrastructures will be defined, especially transport infrastructures, which cross these areas. These criterions are very important to a real integration of infrastructures in territory, avoid barrier effects and create a quality landscape. 


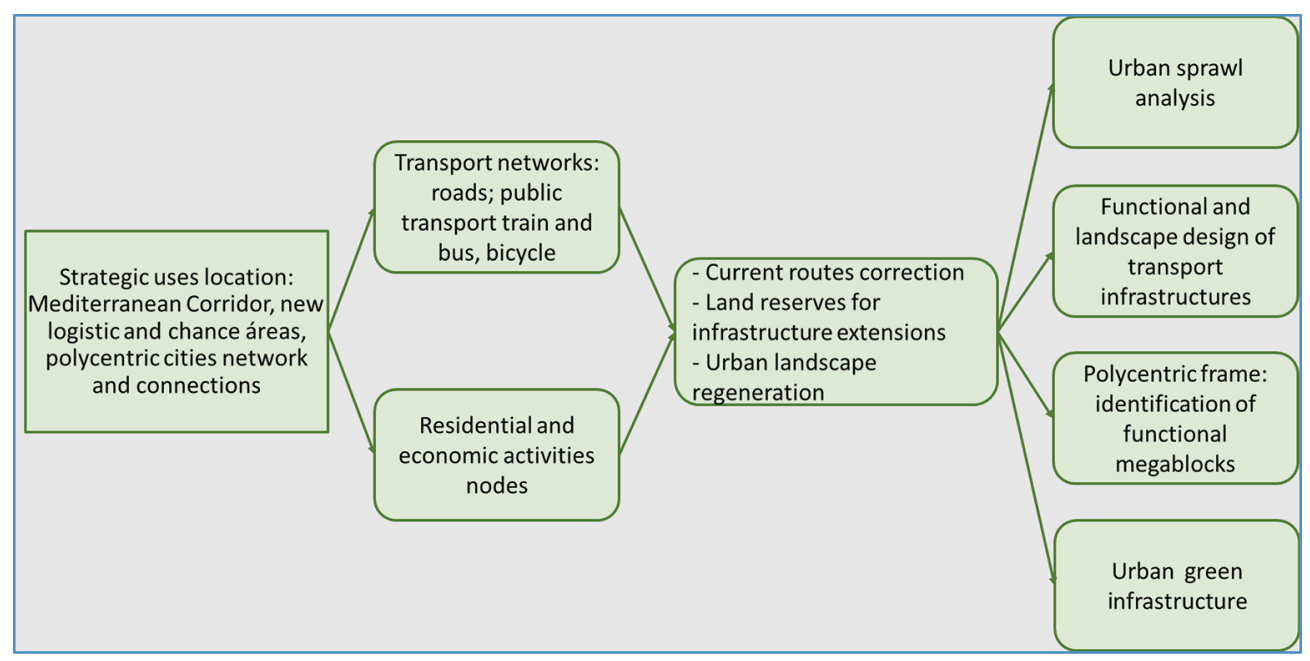

Figure 6: Methodological process to design and integration transport infrastructures in metropolitan areas.

On the other hand, the aptitude analysis allows to identify the lands planned to urban development that currently are not developed but are located in adequate zones to green infrastructure. These zones must change urban planned use to green infrastructure if this change is legal and economically feasible.

In parallel, the demographic analysis and the analysis about land necessary to residential and economic activities uses are carried out, especially, the adequate location where develop areas for economic innovation clusters. These analyses are essential to identify strategic places and infrastructures in metropolitan area in order to guarantee good location and mobility associated to activity according to the concept of transit-oriented development.

Particularly, it is necessary locate the polycentric cities network to design the system of transport network to connect city centres between them.

Figure 6 shows the process to design and integrate transport infrastructures in territory. After locating the strategic uses, in the next phase, must to complete the transport networks (public transport by train and bus, roads and bicycle) and land for residential and economic activities nodes depending on the current urban areas.

In this phase, it will be necessary:

- To revise the routes of different transport modal and correct it, if needed.

- To fix the land reserves for infrastructure extensions.

- To identify actions of urban landscape regeneration.

In this case, the analysis is carried out on a territorial and urban scale because it is necessary to design the routes of transport infrastructures in both scales with adequate section and width.

In the final phase, an analysis of urban sprawl situation with new transport infrastructures is done to avoid unsustainable scenarios, a basic functional and landscape design of transport infrastructures, a final delimitation of mega-blocks or centre nodes and a basic design of urban green infrastructure. 
All these processes allow the generation of a metropolitan plan proposal for its discussion in the environmental strategic assessment procedure in an integrated manner.

\section{CONCLUSIONS}

Metropolitan areas in developed countries are in mature state. In general, the population is stabilized or with low growth while artificial lands increase and density decreases. This situation also occurs in metropolitan and urban areas of the Mediterranean coast.

Metropolitan coastal areas in Spanish Mediterranean coast have a mosaic landscape and had an intense process of urban development especially in last real state bubble period 19972007. Now, it is necessary change the objectives and methods to regional/spatial planning to improve sustainability of urban areas.

According to the analysis carried out for metropolitan area of Valencia as reference area of Mediterranean metropolitan coastal zone, the new criterions for regional/spatial planning must be focused on green infrastructure, system settlement, mobility and SEA.

Green infrastructure is a network of open spaces system connected between them. This network is a Natural Capital for the future that produces a significant list of environmental services for population. This network must be identified for maintaining and improving, and this objective must be priority over others. The methodology for planning metropolitan area based in territorial aptitude method to sustainable urban development (PMABASUD) allow get these objectives according to a logical process.

Given the large amount of already urbanized land and the low growth of the population, system settlement must be focused on regeneration urban land. This system includes a list of nodes with residential and economic activity uses. The economic innovation clusters can be drivers for development: it is necessary to foresee its location.

Mobility is essential to sustainability. The transport system must be designed with criterions of transport-oriented development. That is, transport system must priority public transport and non-motorized modes with intermodal stations in nodes of settlement system. The regional plan must foresee the integration of transport infrastructures in territory to avoid fragmentation and barrier effects and create quality landscape.

In addition, this process to elaborate regional/spatial planning is integrated in SEA process to public participation in decision-making.

The process of regional/spatial planning designed allows to apply sustainability conditions on residential and economic activities in the territory of Mediterranean coastal urban areas.

\section{REFERENCES}

[1] Vheeler, S.M., The evolution of built landscapes in metropolitan regions. Journal of Planning Education and Research, 27, pp. 400-416, 2008, available at www.//jpe.sagepub.com/cgi/content/abstract/27/4/400 (accessed 20 February 2017).

[2] Miralles i Garcia, J.L., El darrer cicle immobiliari al País Valencià. O el progrés de la misèria. Fundació Nexe: València, 2014.

[3] García-Ayllón, S., Retrospective analysis of urban development in the Spanish Mediterranean coast. WIT Transactions on Ecology and the Environment, 179, pp. 291-302, 2013. DOI: $10.2495 / \mathrm{SC} 130251$.

[4] Aguilera, F., Valenzuela, L.M. \& Botequilha-Leitão, A., Landscape metrics in the analysis of urban land use patterns: a case study in a Spanish metropolitan area. Landscape and Urban Planning, 99, pp. 226-238, 2011, available at http://www.sciencedirect. com/science/article/pii/S0169204610002823 (accessed 20 February 2017). 
[5] Feria Toribio, J.M. \& Martínez Bernabeu, L., La definición y delimitación del sistema metropolitano español: permanencias y cambios entre 2001 y 2011. Revista Ciudad y Territorio. Estudios Territoriales, 187, pp. 9-24, 2016. DOI: 10.29057/est.v1i2.1694.

[6] Miralles i Garcia, J.L., Revising the basis for planning a new kind of progress: the case of Valencia's city. WIT Transactions on the Built Environment, 148, pp. 3-14, 2015. DOI: $10.2495 / \mathrm{CC} 150011$.

[7] Council of Europe (CoE), available at https://rm.coe.int/6th-european-conferenceof-ministers-responsible-for-regional-planning/168076dd93 (accesed 20 November 2017).

[8] Miralles i Garcia, J.L., Real estate crisis and sustainability in Spain. WIT Transactions on Ecology and Environment, 150, pp. 123-133, 2011. DOI: 10.2495/SDP110111.

[9] European Commission, available at http://ec.europa.eu/environment/eia/sea-support. htm (accessed 20 January 2018).

[10] European Commission, Communication from the Commission to the European Parliament, the Council, the European Economic and Social Committee and the Committee of the Regions. Green Infrastructure (GI) - Enhancing Europe's Natural Capital, available at http://eur-lex.europa.eu/legal-content/EN/TXT/?uri=CELEX:52013DC0249 (accessed 14 October 2016).

[11] Generalitat Valenciana (GVA), Conselleria d'Habitatge, Obres Públiques i Vertebració del Territori. Estrategia Territorial de la Comunitat Valenciana, available at http://www. habitatge.gva.es/web/planificacion-territorial-e-infraestructura-verde/estrategia-territorial-de-la-comunitat-valenciana-77496 (accessed 20 February 2017).

[12] Generalitat Valenciana (GVA), Conselleria d'Habitatge, Obres Públiques i Vertebració del Territori. Documento de Inicio del proceso de Evaluación Ambiental y Territorial Estratégica del Plan de Acción Territorial Metropolitano de Valencia, available at http:// www.habitatge.gva.es/web/planificacion-territorial-e-infraestructura-verde/plan-deaccion-territorial-metropolitano-de-valencia-pateval- (accessed 20 February 2017).

[13] Boira, J.V., Urbanismo expansivo: de la utopía a la realidad. Proceedings of XXII Congreso de Geógrafos Españoles, Alacant, Spain, pp. 79-90, 2011, available at https:// web.ua.es/va/xxiicongresoage/documentos/comunicacions/ponencia-dues-part1.pdf (accessed 20 February 2017).

[14] Gielen, E., Costes del "Urban Sprawl" para la administración local. Publicacions de la Universitat de València: València, 2016.

[15] Miralles i Garcia, J.L. \& Altur Grau, V.J., Updated method of aptitude to sustainable urban development for including green infrastructure. International Journal of Sustainable Development and Planning, 11, pp. 970-979, 2016. DOI: 10.2495/SDP-V11N6-970-979.

[16] Miralles i Garcia, J.L., Environmental management of peri-urban natural resources: L'Horta de València case study. WIT Transactions on Ecology and the Environment, 192, pp. 99-110, 2015. DOI: 10.2495/ECO150101.

[17] Temes, R. \& Moya, A., Typology of the transformations occurred in the peri-urban space of Huerta de Valencia. Evidence form North Arch of Valencia. International Journal of Sustainable Development and Planning, 11(6), pp. 996-1003, 2016. DOI: 10.2495/SDP-V11-N6-996-1003.

[18] Burriel de Orueta, E.L., La planificación territorial en la Comunidad Valenciana (19862009). Scripta nova, XIII(306), 2009, available at www.ub.es/geocrit/sn/sn-306.htm (accessed 14 October 2016). 
[19] European Commission, available at http://ec.europa.eu/environment/eia/sea-support. htm (accessed 20 January 2018).

[20] Miralles i Garcia, J.L., Green infrastructure on the Mediterranean Valencian coast. International Journal of Sustainable Development and Planning, 11(3), pp. 227-235, 2016. DOI: 10.2495/SDP-V11-N3-227-235.

[21] Estrategia Territorial de la Comunidad Valenciana, Generalitat Valenciana (GVA), Conselleria d'Habitatge, Obres Públiques i Vertebració del Territori, available at www. citma.gva.es/va/web/planificacion-territorial-e-infraestructura-verde/trabajos-previos-76797 (accessed 14 October 2016).

[22] Cervero, R., Ferrell C. \& Murphy S., Transit-oriented development and joint development in the United States: a literature review. Transit Cooperative Research Program. Research Results Digest, 52, 2002.

[23] SOUND TRANSIT, Transit Oriented Development (TOD) Program, available at https://m.soundtransit.org/sites/default/files/20140423_RPT_TOD.pdf (accessed 20 January 2018).

[24] FERRMED, available at www.ferrmed.com (accessed 20 January 2018)

[25] Miralles i Garcia, J.L., The integration of a high-speed train station in Valencia city. WIT Transactions on the Built Environment, 146, pp. 3-14, 2015. DOI: 10.2495/UT150011.

[26] Miralles i Garcia, J.L., Integration of high-speed train stations in cities: the case of Spain and Valencia city. International Journal on Transport Development and Integration, 1(7), pp. 1-18, 2017. DOI: 10.2495/TDI-V1-N7-1-18. 